\title{
Effect of Hot Air Oven Drying on the Moisture Kinetics and Drying Rate of Osmo-Dried Papaya (Carica papaya L.) Slices
}

\author{
Vikrant Kumar*, Jaivir Singh, Ratnesh Kumar, Sunil and Vipul Chaudhary \\ Department of Agricultural Engineering, SVPUAT, MEERUT (UP), India \\ *Corresponding author
}

\section{A B S T R A C T}

\section{Keywords}

Hot air oven dryer, Osmo-dried papaya slices, Moisture content, Drying rate, Self life, Chemical activities, etc.

Article Info

Accepted:

15 January 2019

Available Online:

10 February 2019

\section{Introduction}

Hot air drying often degrades the product quality, provides low energy efficiency and lengthy drying time during the falling rate period. It has been reported that hot-air drying of food materials, involving their prolonged exposure to elevated drying temperatures, results in substantial deterioration of such quality attributes as color, nutrient concentration, flavor and texture (Zaki et al., 2007). In the process, more water than solute is usually removed due to the deferential permeability of cellular membranes (Mauro and Menegalli, 2005). Drying is a technique of conservation that consists of the elimination of large amount of water present in a food by the application of heat under controlled conditions, with the objective to diminish the chemical, enzymatic and microbiological activities that are responsible for the deterioration of foods (Barnabas et al., 2010). Water removal is the main task while preserving food (Lenart, 1996) reducing the moisture contents to a level, which allows safe storage over an extended period of time. Dried foods also present low storage and transportation cost when compared to the 
fresh ones (Okos et al., 1992). The increase in drying rate and decrease of heat transfer provide energy saving of microwave drying. Drying is perhaps the oldest, most common and most diverse of chemical engineering unit operations in the preservation of agricultural food materials or products (Dincer, 1996). It is the process moisture (water) removal from substances due to simultaneous heat and mass transfer (Waewsak et al., 2006). The mechanism of drying process consist of the transport of (mass) moisture from the interior of the solid to the surface, the vaporization of liquid at the surface (diffusion) and the transport of the vapor into gas phase (Seyed $e t$ al., 1999). The drying operation reduces the moisture content of solids to a condition favorable for safe storage without deteriorations. The most significance reason for the popularity of dried products is that in dehydrated foods, microorganisms practically do not grow due to the presence of a minimum amount of water and thus they are immune to enzymatic reactions that could provoke alterations or spoilage in the food (Agarry and Owabor, 2012; Hatamipour et al., 2007; Gumus and Ketebe, 2013).

\section{Materials and Methods}

\section{Experimental plan}

Papaya slices were pretreatment with treatments $\left(\mathrm{T}_{1}=\right.$ Control, $\mathrm{T}_{2}=$ Potassium Metabisulphate, $\mathrm{T}_{3}=$ Sodium bisulphate and $\mathrm{T}_{4}=$ Blanching at $95^{\circ} \mathrm{C}$ for $4 \mathrm{~min}$.) in osmotic solution at temperature of $50^{\circ} \mathrm{C}$. Then the samples were dried under Hot Air Oven drier at $60^{\circ} \mathrm{C}$ temperature. During the process, osmosis was carried out in sucrose solution at a varying concentration of $55^{\circ}$ Brix and $65^{\circ}$ Brix. At each experimental condition, osmotic dehydration was carried out for 180 minutes and data are observed at each $30 \mathrm{~min}$ intervals.

\section{Experimental procedure}

The papaya was procured from the local market of Meerut (UP) in 2018. The papaya was then washed, and decides into $2.5 \times 2.5 \times 2.5 \mathrm{~cm}$ Size. The papaya slices were treated above decided treatments for 30 minutes and then the sample were removed from treated solution and placed at room temperature for 15 minutes and then weighted by electrical balance.

After that the samples were osmosed with sugar solution $\left(55^{\circ} \mathrm{Brix}\right.$ and $\left.65^{\circ} \mathrm{Brix}\right)$ for 180 minutes at $50^{\circ} \mathrm{C}$ temperature and then the osmo-dried papaya slices were dried in Hot Air Oven drying at $60^{\circ} \mathrm{C}$.

\section{Moisture content}

Moisture content of the sample was determined by standard air oven method (Rangana, 2001). Test sample of $5 \mathrm{~g}$ was kept for $16-18 \mathrm{hr}$ in a hot air electric oven maintained at $100^{\circ} \mathrm{C}$. After $16-18 \mathrm{hr}$, sample was drawn from the oven and placed in a desiccator for cooling. After cooling the weight of the sample was taken precisely. The loss in weight was determined and moisture content was calculated using the following expression:

$$
\begin{aligned}
& \text { M C } \%(\mathbf{w b})=\frac{M 1-M 2}{M 0} \times 100 \\
& M ~ C \%(d \mathbf{b})=\frac{M \cdot C \cdot(w b)}{1-M \cdot C \cdot(w b)} \times 100
\end{aligned}
$$

Where,

$\mathbf{M}_{\mathbf{0}}=$ Initial weight of sample taken, $5 \mathrm{~g}$

$\mathbf{M}_{1}=$ Weight of sample before tray drying and weight of dish with cover, $g$

$\mathbf{M}_{2}=$ Weight of the dish with cover containing dried and desiccated sample, $g$ 


\section{Drying rate}

Drying rate will be calculated as weight of water removed per unit time per unit weight of the bone dry matter.

Drying rate $(\%)=\frac{\text { Weight of water removed }(g)}{\text { time }(\min .) \times \text { bone dry weight of the sample }(g)}$

\section{Results and Discussion}

\section{Effect of moisture content during drying}

Fresh Papaya of good and uniform quality was obtained from a local market (Modipuram). The average initial moisture content was $89 \%(\mathrm{wb})$ and soluble solids content was $15^{\circ}$ Brix (Singh, 2015). The effects on moisture content during drying of osmosed dried papaya slices under tray dryer at $60^{\circ} \mathrm{C}$. The result presented in table 1 and figure 1 and 2. Moisture content followed a slight decreasing trend as the drying period increases. The variations in moisture content of osmosed dried papaya slices with time were ranged from 750.79 to $6.92\left(\mathrm{~T}_{1}\right), 223.67$ to $4.84\left(\mathrm{~T}_{2}\right), 245.52$ to $7.19\left(\mathrm{~T}_{3}\right)$ and 235.93 to $2.79\left(\mathrm{~T}_{4}\right)$ of $55^{\circ} \mathrm{Brix}$ from 0 to 660 minutes, while the variations of moisture content were ranged from 772.73 to $16.30\left(\mathrm{~T}_{1}\right), 251.81$ to $4.12\left(\mathrm{~T}_{2}\right), 371.89$ to $9.32\left(\mathrm{~T}_{3}\right)$ and 297.36 to $9.76\left(\mathrm{~T}_{4}\right)$ of $65^{\circ}$ Brix from 0 to 660 minutes. The moisture content decreased as time increases but tend to be constant with further increase in time. The loss in water content of a sample is depending on drying time. In general the time of treatment increase, the weight loss increased but the rate at which this occur decrease (Kumari et al., 2013).

Table.1 Effect of treatments and hot air oven drying $\left(60^{\circ} \mathrm{C}\right)$ on moisture removal of osmo-dried papaya slices

\begin{tabular}{|c|c|c|c|c|c|c|c|c|}
\hline \multirow{2}{*}{$\begin{array}{c}\text { Time } \\
\text { (min.) }\end{array}$} & \multicolumn{2}{|c|}{$\mathbf{T}_{1}$} & \multicolumn{2}{|c|}{$\mathbf{T}_{2}$} & \multicolumn{2}{|c|}{$\mathbf{T}_{3}$} & \multicolumn{2}{|c|}{$\mathbf{T}_{4}$} \\
\hline & $5^{\circ}$ Brix & $65^{\circ}$ Brix & $5^{\circ}$ Brix & $65^{\circ}$ Brix & $55^{\circ}$ Brix & $65^{\circ}$ Brix & $55^{\circ}$ Brix & $65^{\circ}$ Brix \\
\hline 0 & 750.794 & 772.73 & 223.674 & 251.814 & 245.521 & 371.893 & 235.928 & 297.36 \\
\hline 60 & 693.107 & 717.014 & 192.081 & 204.029 & 211.71 & 265.386 & 179.933 & 223.055 \\
\hline 120 & 644.87 & 661.43 & 150.099 & 164.984 & 172.269 & 192.958 & 145.531 & 177.847 \\
\hline 180 & 457.556 & 569.834 & 109.918 & 117.122 & 137.12 & 153.733 & 98.2839 & 116.904 \\
\hline 240 & 337.358 & 456.806 & 82.46 & 76.4046 & 105.985 & 104.066 & 65.694 & 78.4525 \\
\hline 300 & 207.882 & 312.347 & 63.0009 & 56.3851 & 80.1418 & 67.1157 & 49.9151 & 62.9765 \\
\hline 360 & 155.705 & 243.708 & 48.4005 & 47.3862 & 60.6738 & 52.293 & 39.2297 & 47.4985 \\
\hline 420 & 86.2215 & 156.356 & 36.7031 & 35.4526 & 48.4046 & 37.4874 & 31.3507 & 36.0728 \\
\hline 480 & 58.5348 & 113.161 & 27.1505 & 28.2689 & 34.6726 & 30.3976 & 23.5977 & 29.0476 \\
\hline 540 & 30.8531 & 71.2687 & 21.7458 & 18.9684 & 28.9341 & 22.3196 & 16.2551 & 22.8556 \\
\hline 600 & 15.1898 & 53.6365 & 14.5062 & 11.2199 & 19.4922 & 16.4158 & 9.1887 & 16.6661 \\
\hline 660 & 6.91823 & 16.3039 & 4.83995 & 4.11503 & 7.18553 & 9.32241 & 2.78857 & 9.76178 \\
\hline
\end{tabular}


Table.2 Effect of treatments and hot air oven drying $\left(60^{\circ} \mathrm{C}\right)$ on drying rate of osmos-dried papaya slices

\begin{tabular}{|c|c|c|c|c|c|c|c|c|}
\hline \multirow{2}{*}{$\begin{array}{c}\text { Time } \\
\text { (min.) }\end{array}$} & \multicolumn{2}{|c|}{$\mathbf{T}_{1}$} & \multicolumn{2}{|c|}{$\mathbf{T}_{2}$} & \multicolumn{2}{|c|}{13} & \multicolumn{2}{|c|}{$\mathbf{T}_{4}$} \\
\hline & $5^{\circ}$ Brix & $6^{\circ}$ Brix & ${ }^{0}$ Brix & $65^{\circ}$ Brix & ${ }^{0}$ Brix & $65^{\circ}$ Brix & $55^{\circ}$ & $6^{\circ}$ Brix \\
\hline 60 & 1.6144 & 2.06522 & 2655 & .23842 & 56351 & 0.92855 & 0.9333 & 0.79642 \\
\hline 120 & 90198 & 0.8629 & 0.34985 & 0.37673 & 0.32867 & 0.56321 & 367 & 0.32537 \\
\hline 180 & 63 & 7 & 2323 & 0.3 & 27 & & & 590 \\
\hline 240 & 3 & 0 . & 41 & 0. & 73 & 0.4 & & 966 \\
\hline 300 & 1215 & 0.16 & 86 & 0.05 & 14 & 0. & & 0.06673 \\
\hline 360 & 6494 & 0.0 & 0.04 & 0.04 & 0.05408 & 0.29066 & 0.0297 & 0.02800 \\
\hline 420 & 14544 & 0.0478 & 0.02785 & 0.02720 & 0.02921 & 0.20798 & 0.0188 & 0.02641 \\
\hline 480 & & & & & 0.02861 & 0.08999 & 0.0162 & 0.01797 \\
\hline 540 & & 0.0 & & & 0.01863 & 0.07758 & 0.0136 & 0.01422 \\
\hline 600 & & & & & & & & 0.01291 \\
\hline 660 & 0.01253 & 0.0187 & 0.01065 & 0.01046 & 0.01065 & 0.02656 & 0.0097 & 0.01076 \\
\hline
\end{tabular}

Fig.1 Effect on moisture content $(\mathrm{db} \%)$ at $55^{\circ}$ Brix during hot air oven

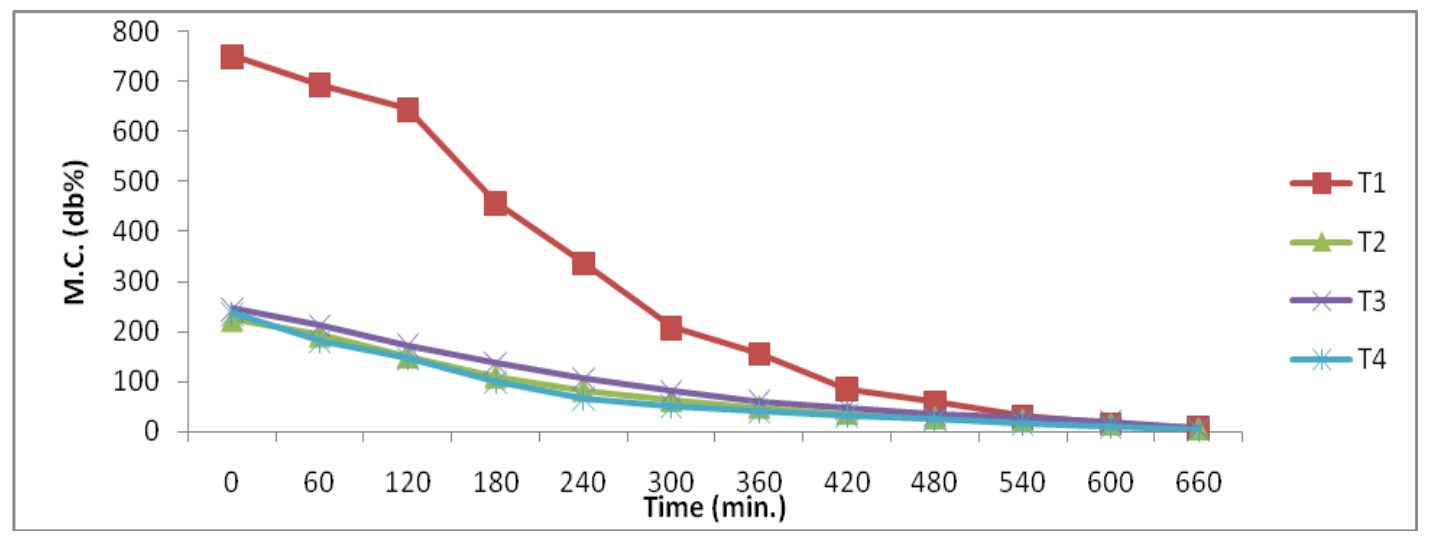

Fig.2 Effect on moisture content $(\mathrm{db} \%)$ at $65^{\circ}$ Brix during hot air oven drying

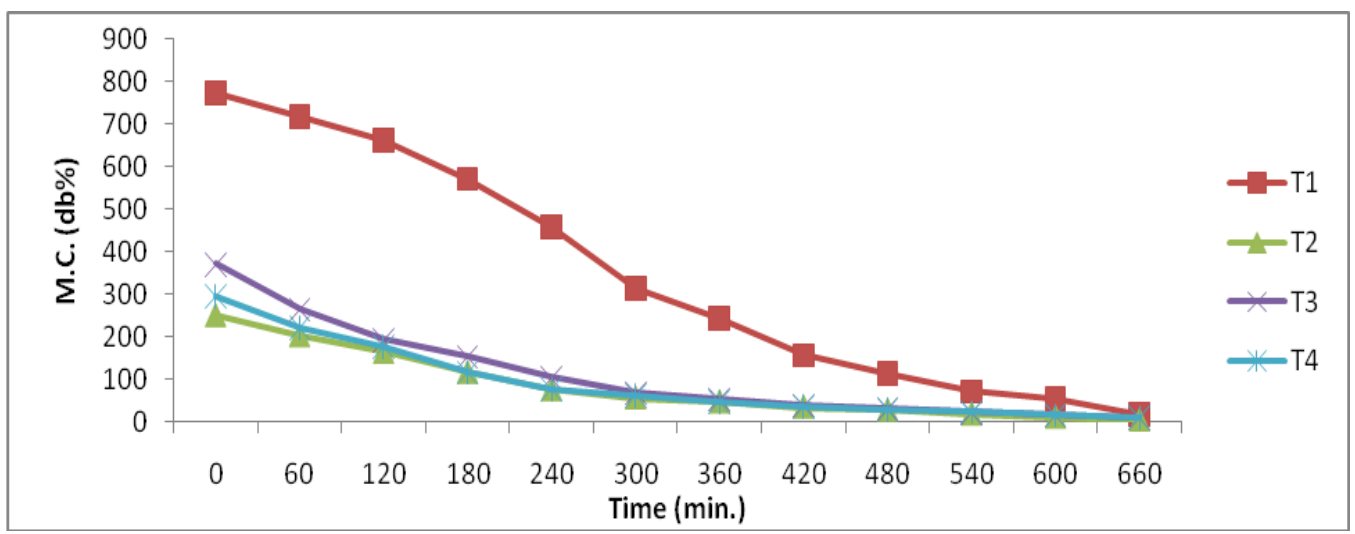


Fig.3 Effect on drying rate at $55^{\circ}$ Brix during hot air oven drying

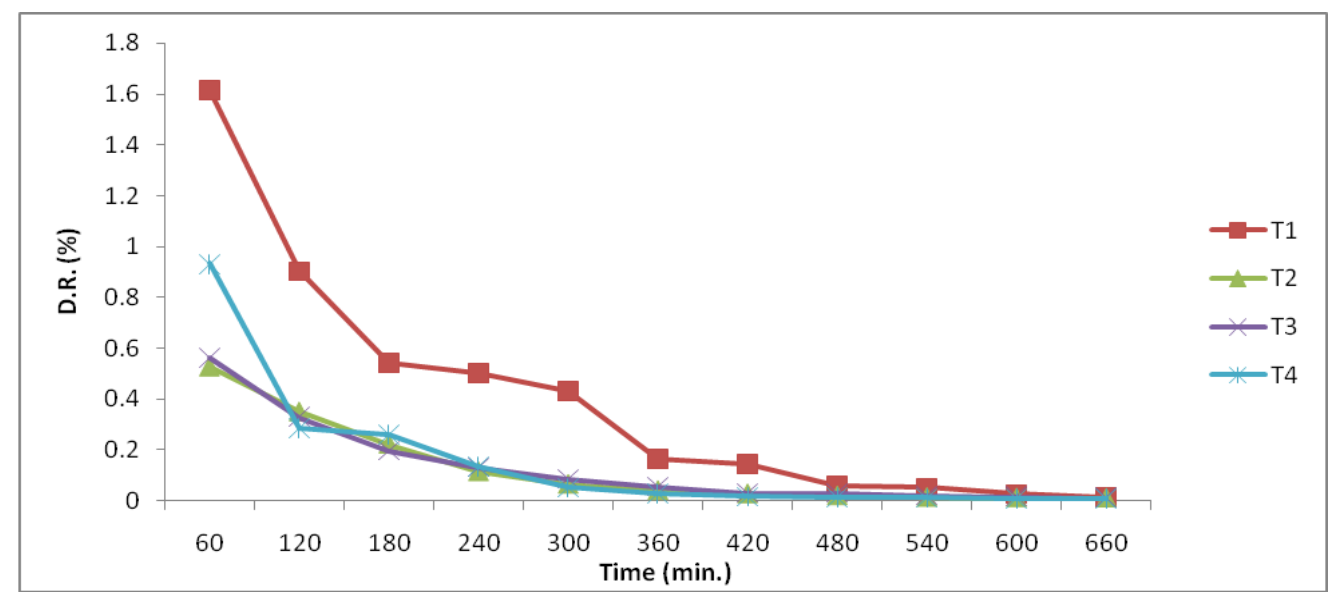

Fig.4 Effect on drying rate at $65^{\circ}$ Brix during hot air oven drying

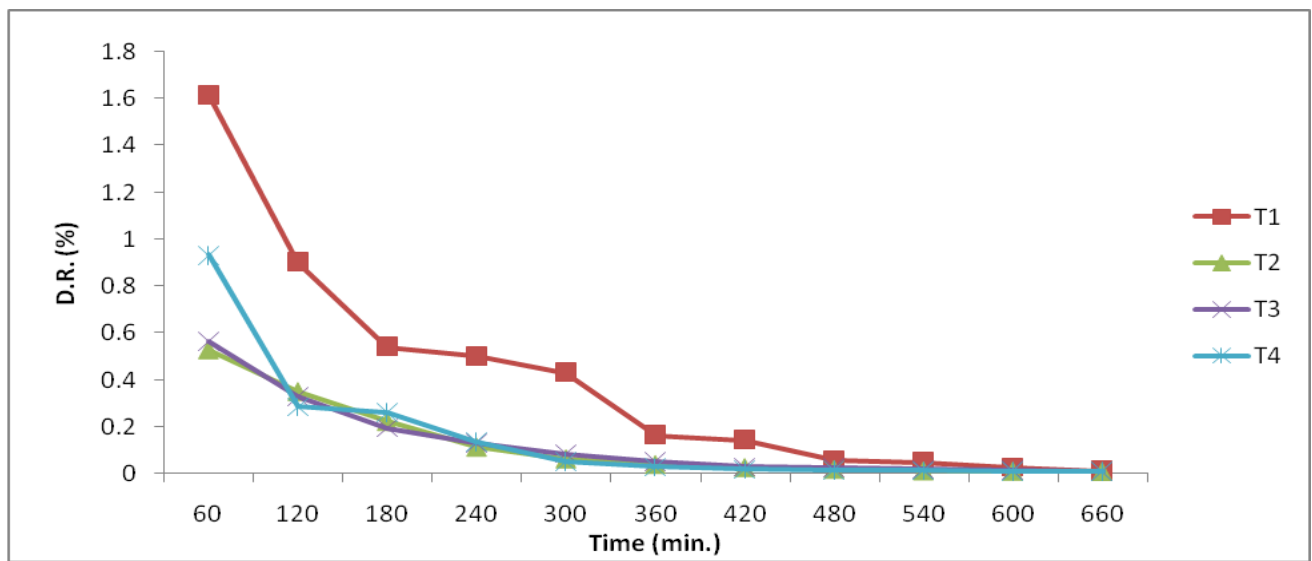

\section{Effect of drying rate during drying}

The drying behavior of osmo-dehydrated papaya slices was analyzed using the experimental data of moisture of product. Time interval varies from 0 to 660 minutes at $60^{\circ} \mathrm{C}$ temperature. The experimental data of the drying behavior of dried papaya slices with relation to moisture content, and drying rate are show in table 2 and figure 3 to 4 . It was observed from the curves that the drying rate was higher in the initial period of drying and subsequently it was reduced with decrease in moisture content. The drying in falling rate period indicates that internal mass transfer occurred by diffusion. Similar results have been reported for the drying studies on onion slices (Rapusas and Driscoll, 1995) and apricots (Doymaz, 2004). The variations in drying rate of osmo-dried papaya slices with time were ranged from 1.61 to $0.013\left(\mathrm{~T}_{1}\right)$, 0.53 to $0.011\left(\mathrm{~T}_{2}\right), 0.56$ to $0.011\left(\mathrm{~T}_{3}\right)$ and 0.93 to $0.009\left(\mathrm{~T}_{4}\right)$ of $55^{\circ} \mathrm{Brix}$ from 60 to 660 minutes, while the variations of drying rate were ranged from 2.065 to $0.019\left(\mathrm{~T}_{1}\right), 1.238$ to $0.010\left(\mathrm{~T}_{2}\right), 0.928$ to $0.026\left(\mathrm{~T}_{3}\right)$ and 0.796 to $0.011\left(\mathrm{~T}_{4}\right)$ of $65^{\circ} \mathrm{Brix}$ from 60 to 660 minutes. The drying rate cure decreased as time increases but tend to be constant with further increase in time. The higher drying rate at the start of drying is due to high surface moisture availability, which evaporates rapidly. Further decrease in drying rate is owed to decrease in available moisture due to low driving force 
and low moisture diffusion from center to surface of the dried product. Similar results were found by (Rocha et al., 1992). Drying time provides an indication of drying rate. Drying rate of the samples was high initially when the moisture content was highest (Kumari et al., 2013). The entire osmotic as well tray drying took place in falling rate period. The final moisture content of samples basically depends upon initial moisture content of the samples, if all conditions are steady.

In conclusion, the drying curves were affected by the drying air temperature. Drying rate was observed from the curves that the drying rate was higher in the initial period of drying and subsequently it was reduced with decrease in moisture content. The drying in falling rate period indicates that internal mass transfer occurred by diffusion. The drying temperature has an essential role in the characterization of drying behavior of papaya samples. The increase in drying time consequently decreases the drying rate. The higher drying rate at the start of drying is due to high surface moisture availability, which evaporates rapidly.

\section{Acknowledgements}

We would like to acknowledge the department of agricultural engineering (S.V.P. Uni. Agri. And Tech. Modipuram, Meerut) for providing facilities to conduct the experiment.

\section{References}

Agarry, S.E. and Owabor, C.N. (2012) Modelling of the drying kinetics of Banana under natural convection and forced air drying. Journal of the Nigerian Society of Chemical Engineers Vol. 27(1): 103-115.

Barnabas, M., Siores, E. and Lamb, A. (2010)
Non-thermal microwave reduction of pathogenic cellular population. International journal of Food Engineering 6:1-18.

Dincer, I. (1996) Sun drying of sultan grapes, Drying Technology, 14: pp. 18271838.

Doymaz. I. (2004) Effect of pre-treatment using potassium metabisulphite and alkaline ethyl oleate on the drying kinetics of apricots. Biosystems engineering, 89:281-287.

Gumus, R.H. and Ketebe, E. (2013) The Effect of Temperature on Drying Rate of Agro Food: Corn (Maize) and Ogbono (Irivingia gabonnensis). Journal of Engineering, Vol. 3(3): 3642.

Hatamipour, M.S., Kazemi, H., Nooralivand, A. and Nozarpoor (2007) Drying characteristics of six verities of sweet potatoes in different dryers. Trans Chemical Part C. Food and Bioproduct processing. Vol. 85(3): 171-177.

Kumari, D., Chandra, S. and Samsher (2013). Assessment of mass transfer properties during osmotic dehydration of ripe banana slice. Beverage and food world, 40(12): 39-42.

Lenart, A. (1996) Osmo-convective drying of fruits and vegetables: technology and application. Drying Technology, 14, 391-413.

Okos, M.R., Narsimham, G., Singh, R.K. and Witnauer, A.C. (1992) Food dehydration. In: D. R. Heldman \& D. B. Lund (Eds.), Handbook of food engineering. New York: Marcel Dekker.

Ranganna, S. (2001). Hand book of Analysis and quality control of fruit and vegetable products. Tata McGraw Hill Pub. Co. Ltd. New Delhi

Rapusas, R.S. and Drisoll, R.H. (1995) Thermo physical properties of fresh 
and dried while onion slices. Journal of Food Engineering, 24: 955-963.

Rocha, T., Lebert, A. and Audoin, C.M. (1992) Effect of drying condition on color of mint and basil (Oumun basilium). A.S. Muyumber (Ed), pp. $1360-66$.

Seyed, J.Y., Moreira, R.G. and Yamseangsung, R. (1999) Superheated steam impingement drying of tortilla chip. Drying Technology. No 17 page 191-213.

Singh, E., Kalyani, B., Reddy, B.S., Kalyani, P.U., Devi, V.H., Ravi, L. and Shanti, M. (2015). Study On dehydration of Papaya Slices Using Osmotic Dehydration Mediated Hot Air Oven
Drying. IOSR Journal of Environmental Science, Toxicology and Food Technology. Vol. 9(11): 7295.

Waewsak, J., Chindaruksa, S. and Punlek, C. (2006) A mathematical modeling study of hot air drying for some agricultural products. Thammasat International Journal of Science and Technology, Vol. 11: pp. 14-20.

Zaki, N.A.M., Muhamad, I.I., Salleh, L.M. and Khairudin, N. (2007) Drying characteristics of papaya during microwave-vacuum treatment. International Journal of Engineering and Technology, Vol. 4(1):15-21.

\section{How to cite this article:}

Vikrant Kumar, Jaivir Singh, Ratnesh Kumar, Sunil and Vipul Chaudhary. 2019. Effect of Hot Air Oven Drying on the Moisture Kinetics and Drying Rate of Osmo-Dried Papaya (Carica papaya L.) Slices. Int.J.Curr.Microbiol.App.Sci. 8(02): 1945-1951. doi: https://doi.org/10.20546/ijcmas.2019.802.226 